\title{
Pemanfaatan Strata Hutan oleh Tikus Ekor Putih (Maxomys hellwaldii) di Gunung Klabat Kabupaten Minahasa Utara, Sulawesi Utara (Utilization of Forest Strates by White Equipment Rats (Maxomys hellwaldii) in Klabat Mountain North Minahasa Distric, North Sulawesi)
}

\author{
Baren Anggyon Rumanasen ${ }^{1)^{*}}$, Saroyo ${ }^{1)}$, Pience Maabuat ${ }^{1)}$ \\ ${ }^{1)}$ Program Studi Biologi FMIPA Universitas Sam Ratulangi, Manado 95115 \\ ${ }^{\star}$ Email korespondensi: rumanasenanggy@gmail.com
}

Diterima 15 Januari 2019, diterima untuk publikasi 28 Februari 2019

\begin{abstract}
Abstrak
Tikus ekor putih (Maxomys hellwaldii) adalah hewan endemik Sulawesi, yang oleh IUCN status konservasinya masih kurang diperhatikan. Ancaman utama tikus ekor putih adalah perburuan untuk dijual. Penelitian ini bertujuan menganalisis pemanfaatan strata hutan oleh tikus ekor putih (Maxomys hellwaldii) di Gunung Klabat Kabupaten Minahasa Utara, Provinsi Sulawesi Utara. Pengamatan menggunakan metode garis transek, dua garis transek dibuat masing-masing pada hutan primer dan hutan sekunder, panjang garis transek masing-masing $2 \mathrm{~km}$ dengan lebar $20 \mathrm{~m}$. Hasil penelitian menunjukkan di hutan primer tikus ekor putih memanfaatkan stratum B sebesar 7,59\%, dan stratum $C$ 92,40\%. Pada hutan sekunder tikus ekor putih memanfaatkan stratum C sebesar $100 \%$. Aktivitas yang dilakukan tikus ekor putih pada hutan primer, mencari makan sebesar 56,96\%, aktivitas berpindah sebesar 30,37\%, aktivitas makan sebesar 5,06\%, dan aktivitas istirahat sebesar 7,59\%. Pada hutan sekunder, sebesar 15,06\%, aktivitas makan (2,73\%),dan aktivitas istirahat sebesar 27,39\%.

Kata kunci: tikus ekor putih, aktivitas, strata hutan, Gunung Klabat
\end{abstract}

\begin{abstract}
White-tailed mice (Maxomys hellwaldii) are endemic to Sulawesi, which by the IUCN (The International Union for Conservation of Nature and Natural Resources) still lacks attention to conservation status. The main threat to white-tailed mice is hunting for sale. The study used the transect line method, two transect lines were made in primary forest and two transect lines were made in secondary forest, the length of the transect line was $2 \mathrm{~km}$ in width and $20 \mathrm{~m}$ in width. The results showed that in primary forest white-tailed mice made use of stratum $B$ of $(7.59 \%)$, and stratum $C$ was (92.40\%). Whereas in the secondary forest white tail rats only use the $C$ stratum, which is equal to $100 \%$. Activities carried out by white-tailed rats were in primary forests, foraging for (56.96\%), moving activities by $(30.37 \%)$, eating activities by (5.06\%), and resting activities at (7.59\%). In secondary forests, whitetailed mice looked for food (54.79\%), shifting activity (15.06\%), eating activities (2.73\%), and resting activities (27.39\%).
\end{abstract}

Keywords: white-tailed mice, activity, forest strates, Klabat Mountain

\section{PENDAHULUAN}

Indonesia merupakan negara kepulauan yang terletak di kawasan tropis antara dua benua (Asia dan Australia) dan dua Samudera (Samudera Hindia dan Samudera Pasifik) yang terdiri atas 17.500 pulau dengan panjang garis pantai sekitar $95.181 \mathrm{~km}^{2}$. Wilayah Indonesia luasnya sekitar 9 juta $\mathrm{km}^{2}$ (2 juta $\mathrm{km}^{2}$ daratan, dan 7 juta $\mathrm{km}^{2}$ lautan). Luas wilayah Indonesia ini hanya sekitar $1,3 \%$ dari luas bumi, namun mempunyai tingkat keberagaman kehidupan yang sangat 
tinggi. Sebanyak 28.000 jenis tumbuhan, 350.000 jenis binatang dan 10.000 mikroba diperkirakan hidup secara alami di Indonesia. Luas daratan Indonesia yang hanya 1,32\% luas seluruh daratan di bumi, ternyata menjadi habitat $10 \%$ jenis tumbuhan berbunga, $12 \%$ binatang menyusui, $16 \%$ reptilia dan amfibia, $17 \%$ burung, $25 \%$ ikan, dan $15 \%$ serangga yang ada di dunia. Dari 515 jenis mamalia besar dunia, 36\% endemik di Indonesia, dari 33 jenis primata, $18 \%$ endemik, dari 78 jenis burung paruh bengkok, 40\% endemik, dan dari 121 jenis kupu-kupu dunia, 44\% endemik di Indonesia (McNeely et al. 1990).

Sulawesi sebagai salah satu pulau di Indonesia merupakan pulau terbesar yang terletak di tengah-tengah kawasan Wallacea yang mempunyai keragaman fauna yang sangat tinggi, di pulau ini hidup 114 jenis mamalia dan 60 jenis di antaranya endemik. Salah satu kekayaan hayati tersebut ialah tikus ekor putih (Maxomys hellwaldii). Tikus ekor putih adalah hewan endemik Sulawesi. Menurut IUCN (The International Union For The Conservation of Nature and Natural Resources), status konservasinya masih kurang diperhatikan (Least concern). Ancaman utama tikus ekor putih adalah perburuan untuk dijual (Saroyo et al. 2012).

Di Sulawesi Utara, tikus ekor putih sudah sejak lama menjadi bahan pangan untuk masyarakat khususnya Minahasa, dikenal dengan nama "turean". Individu dewasa mempunyai warna krem dan warna putih pada bagian dada dan perutnya, ukuran tubuh yang relatif kecil, mencari makan di atas pohon pada malam hari dan berliang di tanah pada siang hari, atau pada lubang-lubang yang ada di pohon. Tikus ini hanya terdapat di hutan-hutan pulau Sulawesi (Corbet dan Hill 1992).

Hutan adalah kesatuan ekosistem berupa hamparan lahan berisi sumber daya alam hayati yang dinominasi oleh tumbuhan pepohonan dalam persekutuan alam lingkunganya, yang satu dengan yang lainnya tidak dapat dipisahkan (UU RI No. 41 Tahun 1999). Sebagaimana telah dikemukakan bahwa hutan tropis terdapat pepohonan yang tumbuh membentuk beberapa stratum tajuk, strata hutan dapat diartikan sebagai suatu lapisan pohon-pohon bertajuk dengan ketinggian yang berbeda di antara batas-batas tertentu. Di dalam hutan tropis, pohon membentuk beberapa stratum yang tersusun di atas yang lain dari beberapa tajuk pepohonan. Di dalam hutan hujan akan didapati tiga stratum bahkan lebih yang dicirikan dengan adanya susunan dari pohon-pohon yang diatur dalam tiga tingkatan yang agak jelas.

Hutan Gunung Klabat adalah salah satu kawasan hutan lindung di Sulawesi Utara terletak di Kabupaten Minahasa Utara, merupakan habitat dari berbagai satwa. Terdapat sekitar $40 \%$ dari luas hutan telah rusak akibat dari perusakan dengan penebangan liar oleh manusia. Sampai saat ini pemanfaatan strata hutan oleh tikus ekor putih di hutan Gunung Klabat belum diketahui, sehingga penelitian tentang aspek tersebut penting untuk dilaksanakan. Penelitian ini bertujuan menganalisis pemanfaatan strata hutan oleh tikus ekor putih (Maxomys hellwaldii) di Gunung Klabat Kabupaten Minahasa Utara, Provinsi Sulawesi Utara.

\section{METODE}

Penelitian ini dilaksanakan pada
bulan Desember 2017 sampai September 2018 di bagian Utara Hutan Gunung Klabat, Kabupaten Minahasa Utara Provinsi Sulawesi Utara

Materi penelitian ialah tikus ekor putih (Maxomys hellwaldii) yang terdapat di hutan Gunung Klabat, Kabupaten Minahasa Utara, Provinsi Sulawesi Utara. Alat-alat yang digunakan dalam penelitian meliputi: binokuler, pita, jam, lembar pengamatan, alat tulis menulis, hand tally counter, kamera, meteran, 
kompas, papan pengalas, senter dan GPS (Global Positioning System).

\section{Parameter yang diamati \\ Pemanfaatan Strata Hutan}

Strata hutan yang dimanfaatkan oleh tikus ekor putih (Maxomys hellwaldii) dikategorikan sebagai berikut sebagai berikut:

1. Stratum A: meliputi ketinggian $40-50$ meter

2. Stratum B: meliputi ketinggian 18-39 meter

3. Stratum C: meliputi ketinggian 4-17 meter

4. Stratum D: meliputi ketinggian 1-3 meter

5. Stratum E: kurang dari 1 meter

\section{Aktivitas tikus ekor putih}

Aktivitas tikus ekor putih (Maxomys hellwaldii) yang teramati selama penelitian dikategorikan sebagai berikut: aktivitas makan (feeding), aktivitas mencari makan (foraging), aktivitas berpindah tempat (moving), aktivitas istirahat (resting), aktivitas sosial (social) yang meliputi menelisik silang (allogrooming), kawin (sexual), bermain (playing), agonistik (agonistic).

\section{Metode Pengumpulan Data}

Pengamatan dilaksanakan pada empat garis transek, dua garis transek dibuat pada hutan primer dan dua garis transek di buat pada hutan sekunder (Tabel 1). Panjang garis transek masing-masing $2 \mathrm{~km}$ dan lebar $20 \mathrm{~m}$. Pengamatan dilaksanakan sebanyak 10 kali untuk setiap transek. Waktu pengamatan mulai jam 19.00 WITA dengan kecepatan pengamatan 2 $\mathrm{km} / \mathrm{jam}$. Data yang diamati meliputi stratum hutan yang dimanfaatkan oleh tikus ekor putih (Maxomys hellwaldii) dan aktivitas yang dilakukan oleh tikus.

\section{Analisis Data}

Data hasil pengamatan diolah secara deskriptif dengan menghitung Persentase pemanfaatan strata hutan dan aktivitas tikus ekor putih (Maxomys hellwaldii).

Tabel 1. Koordinat awal dan akhir pada transek hutan primer dan sekunder

\begin{tabular}{|c|c|c|c|c|}
\hline Hutan Primer & Kordinat Awal & Elevasi & Kordinat Akhir & Elevasi \\
\hline Transek I & $\begin{array}{l}\text { N 01 }{ }^{\circ} 28^{\prime} 25.0^{\prime \prime} \\
\text { E } 125^{\circ} 03^{\prime} 008^{\prime \prime}\end{array}$ & $\begin{array}{l}704 \\
\mathrm{MDPL}\end{array}$ & $\begin{array}{l}N 1^{\circ} 27^{\prime} 35.48 " \\
\mathrm{E} 125^{\circ} 3^{\prime} 16.44 "\end{array}$ & $\begin{array}{l}755 \\
\mathrm{MDPL}\end{array}$ \\
\hline Transek II & $\begin{array}{l}\text { N } 1^{\circ} 28^{\prime} 25.33^{\prime \prime} \\
\text { E } 125^{\circ} 2^{\prime} 57.20^{\prime \prime}\end{array}$ & $\begin{array}{l}706 \\
\mathrm{MDPL}\end{array}$ & $\begin{array}{l}\text { N } 1{ }^{\circ} 28^{\prime} 12.10^{\prime \prime} \\
\text { E } 125^{\circ} 2^{\prime} 19.85^{\prime \prime}\end{array}$ & $\begin{array}{l}751 \\
\text { MDPL }\end{array}$ \\
\hline $\begin{array}{l}\text { Hutan } \\
\text { Sekunder }\end{array}$ & Kordinat Awal & Elevasi & Kordinat Akhir & Elevasi \\
\hline Transek I & $\begin{array}{l}\text { N } 01^{\circ} 28^{\prime} 58.3^{\prime \prime} \\
\text { E } 125^{\circ} 02^{\prime} 05.6^{\prime \prime} \\
\text { N } 1^{\circ} 28^{\prime} 51.23^{\prime \prime} \\
\text { E 125'2'9.00" }\end{array}$ & $\begin{array}{l}600 \\
\text { MDPL } \\
700 \\
\text { MDPL }\end{array}$ & $\begin{array}{l}\text { N 0128'46.88" } \\
\text { E } 125^{\circ} 1^{\prime} 19.21^{\prime \prime} \\
\text { N } 01^{\circ} 288^{\prime} 39.55^{\prime \prime} \\
\text { E } 125^{\circ} 1^{\prime} 15.44^{\prime \prime}\end{array}$ & $\begin{array}{l}730 \\
\text { MDPL } \\
744 \\
\text { MDPL }\end{array}$ \\
\hline
\end{tabular}

HASIL DAN PEMBAHASAN

Pemanfaatan Strata Hutan oleh Tikus Ekor Putih

Jumlah individu selama pengamatan didapatkan sebanyak 79 individu pada hutan primer dan 73 individu pada hutan sekunder. Hasil penghitungan densitas tikus ekor putih (Maxomys hellwaldii) pada hutan primer didapatkan sebesar 0,98 ekor/ha, dan pada hutan Sekunder 0,91 ekor/ha.

Hasil pengamatan pemanfaatan strata hutan oleh tikus ekor putih (Maxomys hellwaldii) didadaptkan bahwa tikus tersebut memanfaatkan beberapa stratum dan aktivitas tikus pada setiap stratum, yaitu dari stratum $A, B, C, D$, dan $E$ tikus lebih dominan melakukan aktivitas pada stratum B 
dan C, yaitu mencari makan dan berpindah.

Pada stratum B, Stratum ini terdiri dari pohon-pohon dengan ketinggian 18-39 meter dengan tajuk yang beraturan (kontinu). Batang pohon umumnya bercabang dan cabang batangnya tidak begitu tinggi. Jenis pohon pada stratum ini kurang memerlukan cahaya atau tahan naungan (toleran). Stratum C Stratum ini terdiri dari pohon-pohon dengan ketinggian 4-17 meter dan bertajuk kontinu. Pohon-pohon dalam stratum ini rendah, kecil dan banyak bercabang. Lapisannya berkesinambungan dan agak rapat.

\section{Pemanfaatan Strata oleh Tikus Ekor Putih di Hutan Primer}

Tikus ekor putih (Maxomys hellwaldii) merupakan hewan nokturnal yaitu melakukan sebagian aktivitas hidupnya pada malam hari seperti, berpindah, makan, diam atau istirahat. Sedangkan kawin, tidur, melahirkan, bermain semua itu dilakukan di dalam lubang sarangnya. Dari 5 stratum yang ada diamati stratum $B$ dan $C$ merupakan stratum yang banyak dimanfaatkan oleh tikus, pada hutan primer persentase aktivitas pada stratum B sebesar 7,59\%, pada stratum C 92,40\% (Tabel 2).

Stratum B dan C lebih banyak dimanfaatkan oleh tikus ekor putih karena, pada kedua stratum ini memiliki bentuk pohon yang rapat, tidak terlalu tinggi dan memiliki percabangan yang banyak, sehingga tikus mampu berjalan dengan baik dan dapat berpindah dari satu pohon ke pohon yang lain untuk mencari makan atau menghindar dari serangan pemangsa.

Pada pengamatan pemanfaatan hutan tidak didapatkan aktivitas tikus pada stratum $A$, namun stratum ini bisa dimanfaatkan oleh tikus dalam mengeksplorasi daerahnya, atau tikus memanfaatkan stratum ini pada saat merasa terancam maka tikus akan berpindah ke stratum $A$ atau stratum lainnya. Begitu juga pada stratum D dan $\mathrm{E}$ tidak didapati tikus melakukan aktivitasnya pada kedua stratum tersebut, namun kedua stratum ini dimanfaatkan oleh tikus saat mulai keluar dari lubang sarangnya tikus akan mulai mencari makan dari stratum paling bawah hingga stratum yang banyak menghasilkan makanan. Menurut Taumimadja dan Kusumamiardja (1985), tingkah laku makan mencakup konsumsi bahanbahan yang bermanfaat bagi tubuh satwa dalam wujud padat maupun dalam wujud cair

\section{Pemanfaatan Strata oleh Tikus Ekor Putih di Hutan Sekunder}

Pada hutan sekunder stratum yang banyak dimanfaatkan oleh tikus ekor putih adalah stratum $\mathrm{C}$ dengan persentase aktivitasnya (100\%) (Tabel 2). Stratum C lebih banyak diamanfaatkan oleh tikus ekor putih karena, pada stratum ini memiliki bentuk pohon yang rapat, tidak terlalu tinggi dan memiliki percabangan yang banyak. Keadaan tersebut menyebabkan tikus mampu berjalan dengan baik dan dapat berpindah dari satu pohon ke pohon yang lain. Perpindahan ini bertujuan untuk untuk mencari makan atau menghindar dari serangan pemangsa, atau ketika merasa terancam tikus langsung berpindah memasuki lubang sarangnya karena stratum $\mathrm{C}$ cukup dekat dengan tanah.

Pada pengamatan di lokasi tidak didapati aktivitas tikus di stratum $A, B, D$, dan $E$, namun tikus dapat memanfaatkan semua stratum dalam berpindah, mencari makan dan istirahat, karena ketika makanan yang berada di stratum $\mathrm{C}$ habis maka tikus akan berpindah mencari makan ke stratum yang lain. Dalam kondisi sumber makanan dan minuman yang melimpah, mahluk hidup cenderung untuk memilih sumber makanan dan minuman yang paling baik yang berasal dari sumber yang paling mudah di dapat dan tempat yang paling aman (Begon et al. 2006). 
Hasil penelitian Wahyuni (2005) melaporkan bahwa cara makan tikus ekor putih berawal dari mendekati pakan, menciumnya lalu mengambil pakan yang disukai dengan kedua kaki depan sambil duduk. Bila pakan yang tidak disukai ditinggalkan kemudian mencari pakan yang lain. Bila ukuran pakan terlalu besar, tikus akan memotongnya kecil-kecil dengan menggunakan mulut, dan bila sudah bisa digenggam dengan kedua kaki depan, baru tikus duduk dan memasukkan ke dalam mulutnya.

Tabel 2. Hasil pengamatan pemanfaatan strata hutan, dan aktivitas tikus ekor putih pada hutan primer

\begin{tabular}{lcccccc}
\hline Aktivitas & \multicolumn{7}{c}{ Hutan Primer } & & Jumlah (\%) \\
\hline \multirow{2}{*}{ Istirahat } & A & B & C & D & E & \\
Makan & 0 & 0 & 6 & 0 & 0 & $6(7,59 \%)$ \\
Mencari Makan & 0 & 0 & 4 & 0 & 0 & $4(5,06 \%)$ \\
Menelisik Silang & 0 & 3 & 42 & 0 & 0 & $45(56,96 \%)$ \\
Agonistik & 0 & 0 & 0 & 0 & 0 & $0(0,00 \%)$ \\
Kawin & 0 & 0 & & 0 & 0 & $0(0,00 \%)$ \\
Bermain & 0 & 0 & 0 & 0 & 0 & $0(0,00 \%)$ \\
Berpindah & 0 & 0 & 0 & 0 & 0 & $0(0,00 \%)$ \\
\hline \multirow{2}{*}{ Jumlah (\%) } & 0 & 6 & 21 & 0 & 0 & $24(30,37 \%)$ \\
& $(0,00 \%)$ & $(7,59 \%)$ & $(92,40 \%)$ & $(0,00 \%)$ & $(0,00 \%)$ & $(100 \%)$ \\
\hline
\end{tabular}

Tabel 3. Hasil pengamatan pemanfaatan strata hutan, dan aktivitas tikus ekor putih pada hutan sekunder

\begin{tabular}{lcccccc}
\hline Aktivitas & \multicolumn{7}{c}{ Hutan Sekunder } & Jumlah (\%) \\
\hline \multirow{3}{*}{ Istirahat } & A & B & C & D & E & \\
Makan & 0 & 0 & 20 & 0 & 0 & $20(27,39 \%)$ \\
Mencari Makan & 0 & 0 & 2 & 0 & 0 & $2(2,73 \%)$ \\
Menelisik Silang & 0 & 0 & 40 & 0 & 0 & $40(54,79 \%)$ \\
Agonistik & 0 & 0 & 0 & 0 & 0 & $0(0,00 \%)$ \\
Kawin & 0 & 0 & 0 & 0 & 0 & $0(0,00 \%)$ \\
Bermain & 0 & 0 & 0 & 0 & 0 & $0(0,00 \%)$ \\
Berpindah & 0 & 0 & 0 & 0 & 0 & $0(0,00 \%)$ \\
\hline \multicolumn{1}{c}{ Jumlah (\%) } & 0 & 0 & 11 & 0 & 0 & $11(15,06 \%)$ \\
\hline
\end{tabular}

\section{KESIMPULAN}

Tikus ekor putih (Maxomys hellwaldii) pada hutan primer memanfaatkan stratum B sebesar $7,59 \%$, dan stratum C 92,40\%, sedangkan pada hutan sekunder tikus ekor putih memanfaatkan stratum C sebesar $100 \%$. Pada hutan primer tikus ekor putih menunjukan aktivitas mencari makan sebesar 56,96\%, aktivitas berpindah (30,37\%), aktivitas makan (5,06\%), aktivitas istirahat sebesar $(7,59 \%)$. Pada hutan sekunder tikus ekor putih menunjukan aktivitas mencari makan sebesar 54,79\%, aktivitas berpindah sebesar (15,06\%), aktivitas makan sebesar (2.73\%), dan aktivitas istirahat (27,39\%). 


\section{DAFTAR PUSTAKA}

Anonim (1999) Undang Undang Nomor 41 Tahun (1999) tentang Kehutanan, Kantor Menteri Negara Sekretaris Negara Republik Indonesia, Jakarta.

Begon M, Townsend CR, Harper JL (2006) Ecology: from individuals to ecosystems. 4th Ed. Blackwell Publishing, Malden

Corbet GB, Hill JE (1992) Mammals of the Indomalayan region: asystematic review. Oxford University Press.

Direktorat Jendral PHPA (1986) Laporan penelitian potensi dan habitat primata di Lampung dan Sumatera Selatan. Direktorat Jendral Perlindungan Hutan dan Pelestarian Alam. Departemen Kehutanan.

IUCN (2008) Redilst. http://www.iucnredlits.org/details/ 12895/0 [09 Oktober 18 (2017)].
McNeely JA, Miller KR, Reid W, Mittermeier R, Werner TB (1990) Conserving the world's biological diversity. IUCN World Resource Institute, Cl, WWF-US, The World Bank, Gland, Switzerland and Washington, D C.

Saroyo, Simbala EIH, Koneri R, Siahaan R, Siahaan P (2012) Biologi konservasi. CV Patra Media Grafindo Bandung.

Tanudimadja K, Kusumamihardja, S (1985) Perilaku hewan ternak. diktat kuliah bagian anatomi Fakultas Kedokteran IPB. Bogor.

Wahyuni I (2005) Tingkah laku reproduksi dan karakteristik daging tikus ekor putih (Maxomys helwalldii). Disertasi. Sekolah PascaSarjana IPB. Bogor. 